http://jmscr.igmpublication.org/home/

ISSN (e)-2347-176x ISSN (p) 2455-0450

crossref DOI: https://dx.doi.org/10.18535/jmscr/v9i4.15

Journal Of Medical Science And Clinical Research

\title{
Knowledge and Practice of Menstrual Hygiene among GNM Nursing Students in a Selected Nursing Institution in Bihar
}

\author{
Authors \\ Samapti Pal ${ }^{1}$, Dr Jogindra Vati ${ }^{2}$ \\ ${ }^{1} \mathrm{Ph}$ D scholar, Himlayan University, Itanagar, Arunachal Pradesh \& Nursing Tutor State Nodal Center, \\ IGIMS College of Nursing, Patna, Bihar \\ ${ }^{2}$ Research Guide at Himalayna UNiversity, Itanagar, Arunachal Pradesh
}

\section{Introduction}

Menstruation is the physiological uterine bleeding that occurs regularly for every reproductive age group of women, from menarche to menopause. It is shedding of the endometrium due to the hypothalamo-pituitary-ovarian axis role. Usually, menstruation lasts for 4-5 days with a heavier flow on the first two days. Menstrual discharge is usually a dark-colored viscous liquid that contains blood, mucus, vaginal epithelial cell, fragments of endometrium, a little bit of prostaglandin, and enzymes. All these make it a favorable environment for micro-organism growth. So, maintenance of hygiene during menstruation flow is essential. Poor menstrual hygiene leads to several reproductive tract and urinary tract infections. Candidiasis, fungal infections are most common, whereas it can also lead to Human Papilloma Virus infection which can cause cervical cancer. Studies have shown that not upholding hygiene makes women prone to all types of Sexually Transmitted Infections(STIs) including Human Immunodeficiency Virus (HIV).Studies have also revealed that improper menstrual hygiene predisposes women to some communicable diseases and it can also hamper daily life. ${ }^{1}$
Nursing students belong to the late adolescent to teenager group. For decades, studies have been done to check the knowledge and practice on the topic of menstrual hygiene. A study conducted in Bangladesh in 2015 has shown more than $50 \%$ of the participants were having only a moderate level of knowledge and they were not told about menstrual cycles before leading to shocking reactions when it started. ${ }^{2}$ Another study done in West Bengal, India has shown that discussion on menstruation is still considered taboo and there is a restriction of worship or food intake during the bleeding days. Daily bathing during the menstrual days is not very regular for adolescents, however,the older age group had shown better regularity in maintaining hygiene. ${ }^{3}$ Another descriptive study done in Tamilnadu, comes with a surprising result showing only $3 \%$ of the nursing students who participated in the study were having good knowledge. The same study also showed that $70 \%$ of the students are having inadequate knowledge about menstrual hygiene. However, $50 \%$ of the students are practicing hygiene adequately. ${ }^{4} \mathrm{~A}$ systematic review of health and social effects of menstrual hygiene has found a direct association of Menstrual Hygiene Management (MHM) with Reproductive Tract 
Infection (RTI) prevalence. Meta-analysis has also shown a great impact of structured education at the right time to avoid or lower the occurance. ${ }^{5}$ hence, the importance of MHM is obvious.

Several other studies have been done on the different parts of the globe, but in Bihar, a study pertinent to assess knowledge and practice of menstrual hygiene exclusively among nursing students has not yet been explored through any research. Given the fact that nurses are the backbone of the healthcare system, the first point of contact of the community to provide direct care and also comprehensive case including counseling and public awareness. Therefore, proper knowledge and practice of MHM are extremely necessary for the nursing student who in near future is going to serve the community in various ways. Hence, a study has been planned to explore the knowledge and practice of menstrual hygiene among the General Nursing and Midwifery students in a selected Govt Nursing school in Bihar.

\section{Objectives}

1. To assess knowledge and practice of menstrual hygiene of the General Nursing and Midwifery students of selected Nursing Institution.

2. To find an association with selected demographic variables.

\section{Methodology}

The study was done at the GNM nursing students of GNM Nursing Institute, Sri Krishna Medical College and Hospital (SKMCH), Muzzafarpur, Bihar.

Research Approach and Design: A descriptive cross-sectional study design was planned to conduct the study.

Assumption: Nursing students, being part of the health care provider team will have basic knowledge about menstrual hygiene.

Population: The target population was first, second-, and third-year nursing students of GNM Institute, SKMCH.

\section{Sample and Sampling Technique}

The study was designed to include all the nursing students present at the institute at the time of data collection. The students were assessed on a predetermined, structured, pre-tested questionnaire. Permission was taken from the Head of the Institute, Principal and also all the students were informed verbally and then written consent was taken before participating in the study.

Instruction was given to keep their response anonymous, coding was done according to their classroom enrolment number. Three sets of questions were given to them comprising sociodemographic information, knowledge and, practice-related questions. The questionnaire took about 15 minutes to complete per student. All the respondents were assured of confidentiality and told that the data will be used only for research purposes.

\section{Inclusion Criteria}

Nursing students of GNM Institute, SKMCH were included.

\section{Exclusion Criteria}

Students who are not willing to participate in the study were excluded.

Students who were not present during the data collection were excluded.

Tool:

1. Socio-demographic profile: Age, standard, mother's education, father's education, monthly income per capita, religion, type of family.

2. Structured Questionnaire on knowledge assessment: The questionnaire consists of a total of 8 questions. Questions were a mix of multiple-choice, open-ended and, yes/no type. Question number 2 and 3 were not to be scored, all other questions were having a score of 1 for the correct answer and 0 for the wrong answer. The total maximum score can be 5, 3 and, below is considered as inadequate knowledge. 4-5 is considered as good knowledge. 
3. A structured questionnaire on practice assessment: The questionnaire consists of a total of 7 questions assessing their practice during menstruation. 5 and below is considered as having a not good practice, whereas $6-7$ is considered to have good practice related to menstrual hygiene.

\section{Results}

Collected data was organized and entered into Epi-info version 3.5.1 and exported to SPSS for windows version 20.0 for analysis.

The study results showed that the majority of the students were in the age group of 21- 24 years, $48.5 \%$, followed by $17-20$ years $(35.6 \%)$ and 16.1 $\%$ belong to the age group pf 24-27 years.
Maximum students had an educational background of Higher secondary (84.2\%), only $4.2 \%$ students were having education of Masters andabove. Whereas the majority of the mother's education level is found to be secondary $(51.7 \%)$, the majority of fathers education is Graduation and above $(50.8 \%)$, followed by higher secondary $(33.1 \% \& 30.5 \%)$ respectively. Most of the students $67.8 \%$ are staying in the hostel with friends, $32.2 \%$ of students are staying at home. Monthly income per capita $48.3 \%$ belong to upto Rs 20,000/ , 33.9\% above Rs. 30,000/ and 17.8\% Rs. 21,000/- Rs. 30,000/ respectively. Students who participated in the study $59.3 \%$ from joint family whereas $40.7 \%$ from a nuclear family. All the students were Hindu, no other religion was found during the study at the school.

\begin{tabular}{|c|c|c|c|}
\hline Variable & & Frequency & Percentage \\
\hline \multirow[t]{3}{*}{ Age } & $17-20$ years & 42 & 35.6 \\
\hline & $21-24$ years & 57 & 48.3 \\
\hline & $24-27$ years & 19 & 16.1 \\
\hline \multirow[t]{3}{*}{ Education } & Higher Secondar & 100 & 84.7 \\
\hline & Graduation & 13 & 11.0 \\
\hline & Masters and above & 5 & 4.2 \\
\hline \multirow[t]{2}{*}{ Living with } & hostel & 80 & 67.8 \\
\hline & home & 38 & 32.2 \\
\hline \multirow{3}{*}{$\begin{array}{l}\text { Mother's } \\
\text { education }\end{array}$} & secondary & 61 & 51.7 \\
\hline & Higher secondary & 39 & 33.1 \\
\hline & Graduation and above & 18 & 15.3 \\
\hline \multirow{3}{*}{$\begin{array}{l}\text { Father's } \\
\text { education }\end{array}$} & Secondary & 22 & 18.6 \\
\hline & Higher Secondary & 36 & 30.5 \\
\hline & Graduation and above & 60 & 50.8 \\
\hline \multirow[t]{3}{*}{ Monthly income } & UptoRs. 20,000/ & 57 & 48.3 \\
\hline & Rs. 21,000 -Rs $30,000 /$ & 21 & 17.8 \\
\hline & Above Rs. 30,000/ & 40 & 33.9 \\
\hline \multirow{2}{*}{ Type of Family } & Nuclear & 48 & 40.7 \\
\hline & Joint & 70 & 59.3 \\
\hline \multirow{4}{*}{$\begin{array}{ll}\text { Source } \\
\text { information }\end{array}$} & friends & 22 & 18.6 \\
\hline & family & 82 & 69.5 \\
\hline & media & 6 & 5.1 \\
\hline & others & 8 & 6.8 \\
\hline
\end{tabular}

The study result shows that majority of the students are having good knowledge (81.4\%), only $18.6 \%$ of students have inadequate knowledge regarding menstrual hygiene.The same pattern can be seen in the cases of practice menstrual hygiene, in which $72.9 \%$ are following good menstrual hygiene practices, $27.1 \%$ are not. Cleaning of external genitalia with soap and water was reported by 95 of the students $(80.5 \%), 13$ students said they clean their genitalia with clean water only and 10 of them said they do not clean during menstruation. 
The data collected shows all the students have heard about menstruation and 82 of them, $69.5 \%$ have heard from family. Rest $18.6 \%$ from friends,
$5.1 \%$ from media and, $6.8 \%$ from other sources have learned about menstruation.

\begin{tabular}{lcc}
\hline Knowledge & & \\
\hline good knowledge & 96 & 81.4 \\
\hline inadequate knowledge & 22 & 18.6 \\
\hline Practice & & \\
\hline GOOD practice & 86 & 72.9 \\
\hline not good practice & 32 & 27.1 \\
\hline
\end{tabular}

The study also shows that majority of the students who are practicing good menstrual hygiene have good knowledge about menstruation. On the other side, some of the students irrespective of their inadequate knowledge level are practicing good menstrual hygiene and vice versa.

When comparing between age group and knowledge level, data shows that age group of 2427 years is having maximum mean (1.26) and standard deviation 0.452, whereas 21-24 years and 17-20 years are having a mean and standard deviation of $1.17,1.16$ and, 0.383 and 0.377 respectively.

During comparison between age group and practice, it is shown that the age group of 24-27 years having better practice than other groups with a mean of 1.42 and standard deviation of 0.507 . rest of students irrespective of their age group are having the same mean of $1.23 \pm$ and standard deviation of $0.431 \pm$. So highest level of knowledge and good practice both are seen among the age group of 24-27 years.

\begin{tabular}{|c|c|c|c|c|c|}
\hline Variable & & Mean (K) & $\begin{array}{l}\text { Standard } \\
\text { deviation }\end{array}$ & Mean (P) & $\begin{array}{l}\text { Standard } \\
\text { deviation }\end{array}$ \\
\hline \multirow[t]{3}{*}{ Age } & $17-20$ years & 1.166 & 0.377 & 1.2381 & .43108 \\
\hline & $21-24$ years & 1.175 & 0.383 & 1.2456 & .43428 \\
\hline & $24-27$ years & 1.263 & 0.452 & 1.4211 & .50726 \\
\hline \multirow[t]{3}{*}{ Education } & Higher Secondar & 1.1700 & .37753 & 1.2700 & .44620 \\
\hline & Graduation & 1.1538 & .37553 & 1.2308 & .43853 \\
\hline & Masters and above & 1.6000 & .54772 & 1.4000 & .54772 \\
\hline \multirow[t]{2}{*}{ Living with } & hostel & 1.1875 & .39277 & 1.2625 & .44277 \\
\hline & home & 1.1842 & .39286 & 1.2895 & .45961 \\
\hline \multirow{3}{*}{$\begin{array}{l}\text { Mother's } \\
\text { education }\end{array}$} & secondary & 1.1148 & .32137 & 1.2951 & .45986 \\
\hline & Higher secondary & 1.3077 & .46757 & 1.2051 & .40907 \\
\hline & Graduation and above & 1.1667 & .38348 & 1.3333 & .48507 \\
\hline \multirow{3}{*}{$\begin{array}{l}\text { Father's } \\
\text { education }\end{array}$} & Secondary & 1.0909 & .29424 & 1.2727 & .45584 \\
\hline & Higher Secondary & 1.2778 & .45426 & 1.3611 & .48714 \\
\hline & Graduation and above & 1.1667 & .37582 & 1.2167 & .41545 \\
\hline \multirow[t]{3}{*}{ Monthly income } & uptoRs. 20,000/ & 1.1754 & .38372 & 1.2982 & .46155 \\
\hline & Rs. $21,000-$ Rs $30,000 /$ & 1.2857 & .46291 & 1.2857 & .46291 \\
\hline & Above Rs. 30,000/ & 1.1500 & .36162 & 1.2250 & .42290 \\
\hline \multirow[t]{2}{*}{ Type of Family } & Nuclear & 1.187 & 0.394 & 1.2708 & .44909 \\
\hline & Joint & 1.185 & 0.391 & 1.2714 & .44791 \\
\hline \multirow[t]{4}{*}{$\begin{array}{l}\text { Source } \\
\text { information }\end{array}$} & friends & 1.2727 & .45584 & 1.3182 & .47673 \\
\hline & family & 1.1829 & .38899 & 1.2439 & .43208 \\
\hline & media & 1.1667 & .40825 & 1.3333 & .51640 \\
\hline & others & 1.0000 & .00000 & 1.3750 & .51755 \\
\hline
\end{tabular}

Considering the education, students belonging to the master and above level of education group are having the highest level of knowledge with a mean of $1.6 \pm$ and standard deviation of $0.547 \pm$. 
students belonging to the higher secondary group are having a mean of $1.17 \pm$ and standard deviation of $0.377 \pm$, the Graduation group mean is $1.15 \pm$ and standard deviation $0.375 \pm$.

Mothers and Fathers education level have shown the highest mean among the higher secondary educated group with the mean $1.3 \pm$ and 1.27 \pm , standard deviation $0.467 \pm$ and $0.454 \pm$.

Religion and type of family have been statistically found to have the same knowledge and practice among the students.

\section{Association}

\begin{tabular}{lcccc}
\hline Variable & Chi-Square & df & p & significance \\
\hline $\begin{array}{l}\text { Association with the level of } \\
\text { knowledge }\end{array}$ & & & & \\
\hline Age & 0.891 & 2 & 0.641 & Not significant \\
\hline Education & 5.907 & 2 & 0.108 & Not significant \\
\hline Living with & 0.002 & 1 & 0.966 & Not significant \\
\hline Mother's education & 5.89 & 2 & 0.053 & Significant \\
\hline Father's education & 3.458 & 2 & 0.177 & Not significant \\
\hline Monthly income & 1.76 & 2 & 0.415 & Not significant \\
\hline Type of family & 0.001 & 1 & 0.98 & Not significant \\
\hline Source of information & 2.935 & 3 & 0.402 & Not significant \\
\hline Association with practice & & & & \\
\hline Age & 2.580 & 2 & 0.275 & Not significant \\
\hline Education & 0.528 & 2 & 0.768 & Not significant \\
\hline Living with & 0.095 & 1 & 0.758 & Not significant \\
\hline Mother's education & 1.389 & 2 & 0.499 & Not significant \\
\hline Father's education & 2.376 & 2 & 0.305 & Not significant \\
\hline Monthly income & 0.665 & 2 & 0.717 & Not significant \\
\hline Type of family & 0.000 & 1 & 0.994 & Not significant \\
\hline Source of information & 1.108 & 3 & 0.775 & Not significant \\
\hline
\end{tabular}

Statistically significant has been found only with the education of the mother with the level of knowledge among the students. All other sociodemographic information like age, education, father's education, monthly income, type of family and, source of information are found to be not significant with either knowledge or practice of the study participants.

\section{Discussion}

Menstrual hygiene is one of the basic hygiene practices that is required to maintain the reproductive health as well as psychological health of every woman of the reproductive age group. But unfortunately in our country still we are struggling to make it a regular practice and removing the taboos related to this. In this study, the result has shown that more than $48 \%$ of participants are in the age group of 21-24 years of age, and $87.4 \%$ of students are having education levels marked as higher secondary. The study is supported by the study done by Tanvi $^{6}$ et all where the majority of the respondents were having the same educational background.

The study revealed that the majority of the students $(96 \%)$ are having good knowledge and $82 \%$ practicing better menstrual hygiene regarding menstrual hygiene. The report is contradicted by the study done by Shivaleela et all, in which it is shown only $60.9 \%$ of the participants were having good knowledge and $39.9 \%$ are having good practice respectively.

The study has shown higher educational level, higher knowledge and, better practice is observed among the study participants. Also higher the mother's education level better knowledge and practice present in the respondent. This is also supported by Shivaleela.

Regarding the source of information about menstrual hygiene, respondents who received information from the friends are showing the highest mean value of $1.2727 \pm$. students who got 
information from others are less knowledgeable with a mean of $1.00 \pm$.

The study revealed that the highest level of knowledge and good practice has been followed by the age group of 24-27 years which issupported by the study done by Nirmalya ${ }^{3}$ et all. In the study, it was reported that senior students, $2^{\text {nd }}$-year students were practicing better hygiene. Cleaning of external genitalia is higher among second-year students. Hence, it can be concluded that with growing age women are becoming mature and more alert about menstrual hygiene and practices.

The only significance with the sociodemographic was related to the educational level of the mother. So here again it can be said that ultimately all better practice comes with education. It is supported by previous studies like Niru et all etc., hence, it can be concluded that a mother's education does make difference in the knowledge level of the daughters.

\section{Conclusion}

The study was mainly aimed to find the knowledge and practice of GNM students regarding menstrual hygiene. The results were quite hopeful, showing there is moderate to a good level of knowledge among majority of the students and also most of them are practicing it. But,there is still room for improvement as it is observed that not all the women who are going to become health care providers and the first contact of the community people and direct caregivers need to be one hundred percent convinced and aware of the basic health practices. Therefore, it is recommended that emphasis should be given to the practice of good menstrual hygiene.

\section{Acknowledgement}

The author is precisely indebted and uttering heartfelt gratitude to Mrs Rekha Prasad, Principal, GNM Institute, SKMCH for her enourmous support and motivation.

\section{Declaration \\ Funding: Nil.}

Conflict of Interest: None.

Ethical Approval: The study was ethically approved from the Institute and the Principal of the GNM Institute. Informed consent was taken from all the participants.

\section{References}

1. India Bhavik Rana, Arpit Prajapati, K. N. Sonaliya, VenuShah, Mansi Patel, Asha Solank, An Assessment of Menstrual Hygiene Practices amongst Adolescent Females at Kheda District of Gujarat State,

2. NiruShamsun Nahar1,2, Ratna Khatun1, KhondokerMahmudaAkter Halim2, Sharmin Islam1, Faisal Muhammad3, Assessment of knowledge and practice of menstrual hygiene among the female nursing students in a selected private nursing college in Dhaka City, International Journal of Reproduction, Contraception, Obstetrics and Gynecology Nahar NS et al. Int J Reprod Contracept Obstet Gynecol. 2019 May;8(5):18471851 www.ijrcog.org pISSN 2320-1770 | eISSN 2320-1789

3. Dr.Nirmalya Manna1 ,Dr. Arista Lahiri2 , Dr.Atanu Bhattacharjee3 , Siddhartha Bera4, Knowledge, Awareness and Practices on Menstrual Hygiene Management among Under-Graduate Nursing Students: Experience from a Cross-Sectional Study in West Bengal, India, IOSR Journal of Dental and Medical Sciences (IOSR-JDMS) e-ISSN: 22790853, p-ISSN: 2279-0861.Volume 18, Issue 1 Ver. 2 (January. 2019), PP 01-06 www.iosrjournals.org DOI: 10.9790/08531801020106 ww.iosrjournals.org 1 | Page

4. P. M. Joanna Rachel \&Dr. Veena M Joseph ,A Descriptive Study to Assess the Knowledge and Practice on Menstrual Hygiene Among Nursing Students in Selected Nursing Colleges in Kanchipuram District, Tamil Nadu, India,, International Journal of Current Research and Modern 
Education, Volume 2, Issue 2, Page Number 53-57, 2017.

5. Colin Sumpter * and Belen Torondel, Systematic Review of the Health and Social Effects of Menstrual Hygiene Management, PLoS One. 2013; 8(4): e62004.Published online 2013 Apr 26. doi: 10.1371/journal.pone.0062004PM CID: PMC3637379PMID: 23637945A

6. Tanvi Nitin Deshpande, ${ }^{1}$ Supriya Satish Patil, ${ }^{1}$ SupritiBalaram Gharai, ${ }^{1}$ S. R. Patil, $^{2}$ and P. M. Durgawale, Menstrual hygiene among adolescent girls - A study from urban slum area ${ }^{1}$

7. Belayneh, Z., Mekuriaw, B. Knowledge and menstrual hygiene practice among adolescent school girls in southern Ethiopia: a cross-sectional study. BMC Public Health 19, 1595 (2019). https://doi.org/10.1186/s12889-019-79739

8. Mahajan A, Kaushal K.a descriptive study to assess the knowledge and practice regarding menstrual hygiene among adolescent girls of Government School of Shimla, Himachal Pradesh, CHRISMED JHealth Res [serial online] 2017 [cited 2021 Apr 3]; 4:99-103.

9. Upashe, S.P., Tekelab, T. \&Mekonnen, J. Assessment of knowledge and practice of menstrual hygiene among high school girls in Western Ethiopia.BMC Women's Health 15, 84 (2015). https://doi.org/10.1186/s12905-015-02457

10. Acharya AS, Tiwari N, Rasania SK, Khandekar J, Bachani D. Assessment of menstrual hygiene among adolescent girls of East Delhi: A community-based crosssectional research from an urban resettlement colony. Indian $\mathrm{J}$ Community
Fam Med [serial online] 2019 [cited 2021 Apr 3];5:141-6. Available from: https://www.ijcfm.org/text.asp?2019/5/2/1 41/273528. 